\title{
The Potential of Fintech in Enhancing the Use of Salam Contract in Islamic Banking
}

\author{
Aishath Muneeza \\ INCEIF (International Centre for Education in Islamic Finance), Malaysia \\ Corresponding email: muneeza@inceif.org \\ Zakariya Mustapha \\ University of Malaya, Malaysia, zakariyamustapaha@gmail.com \\ Article History \\ Received: April $24^{\text {th }}, 2020$ Revised: July $11^{\text {th }}, 2020$ Accepted: July $20^{\text {th }}, 2020$
}

\begin{abstract}
An Islamic banking system employs different Shariah contracts to develop and offers products and services in different jurisdictions. One of such contracts is salam which is a forward sale contract. This study aims to examine the practice of salam as an instrument of Islamic banks financing and how technology can be used to enhance its application thereto. A qualitative approach is employed in this research where primary data sources on salam contract were examined, along with content analysis of relevant secondary data sources on the contract and how its practiced in Islamic banking. In furtherance of that practice, salam instrument can be leveraged on technology, mainly the blockchain. This would enhance its operation by bringing about automation, transparency, fair pricing, saving time and cost as well as enabling widespread access of Islamic bank financing to smaller enterprises to promote societal well-being. This research reveals that salam instruments cater for different clients' needs and enjoy patronage in many jurisdictions even though it is currently the least utilized contract in Islamic banks financing due to divergence of juristic views on its general permissibility. Also, salam is an exceptional contract for Islamic banks financing of agriculture and related enterprises among others. The research offers an insight for Islamic banks to leverage on technology in utilizing salam contract towards providing financing for variety of clients, particularly poor farmers. Similarly, jurisdictions not practicing salam stand to learn of the benefits of using salam to offer technologically innovative yet affordable Islamic banking products/services for variety of clients.
\end{abstract}

Keywords: Blockchain technology, exceptional contract, fintech, Islamic banking, salam JEL Classification : Z19; P19; P29; P48; P49

@ IJIEF 2020 published by Universitas Muhammadiyah Yogyakarta, Indonesia All rights reserved

DOI:

https://doi.org/10.18196/ijief.3231

Web:

https://journal.umy.ac.id/index.php/ijief/article/view/8685

Citation:

Muneeza, A., \& Mustapha, Z. (2020) The Potential of Fintech in Enhancing The Use of Salam Contract in Islamic Banking. International Journal of Islamic Economics and Finance (IJIEF), 3(2), 305-334. DOI: https://doi.org/10.18196/ijief.3231 
Muneeza \& Mustapha $\mid$ The Potential of Fintech in Enhancing The Use of Salam Contract in Islamic Banking

\section{Introduction}

\subsection{Background}

Islamic banking is a system of banking introduced and developed by Islamic scholars from Islamic commercial jurisprudence as a substitute to conventional banking. This is with view to enable Muslims attain economic empowerment via lawful means of financing. These means of financing are formulated using varieties of Shariah contracts for commercial activities. There are different Shariah contracts upon which varieties of Islamic financial services and products are structured to suit the needs of customers. These include mudarabah, musharakah, ijarah, istisna, bai bithaman ajil (BBA), bai' as-salam or salam as it is commonly called, etc. In its literal meaning as an Arabic word, the word salam means to advance. However, in the Islamic commercial parlance, salam specifically connotes a contract where a purchaser pays price for a subject matter in advance and its delivery is postponed to a specified future time. It may be regarded as an Islamic banking's equivalent of forward sale contract (Amine, 2008). Salam is one kind of a Shariah contract that is, to a large extent, used for Islamic microfinance (Obaidullah, 2015; Ehsan \& Shahzad, 2015) and comparatively least utilized in commercial Islamic banking (Muneeza et.al., 2011). This is not unconnected with the fact that salam contract is susceptible to risks more than other Shariah contracts used in commercial Islamic banking. Thus, in certain jurisdictions including Malaysia, one finds no Islamic bank utilizing this contract in providing financial services and products (Muneeza et.al., 2011; p.139). Accordingly, the use of salam contract in Islamic banking is generally limited and risk mitigation tools are strategically employed while applying this contract in Islamic banking (Obaidullah \& Mohamed-Saleem, 2008).

Islamic banking has the objective of serving both rich and poor for the improvement of people living standard. Furthermore, Islamic banking equally seeks to develop economy by increasing real economic activities as the backbone of any economy through engaging in real business activities including sale, lease or partnership engagements with customers/clients. As such, Islamic banking products are, in both theory and practice, always formulated in order to cater for the needs of different segments of society and always linked to activities that have positive impact on the real economy. It is undeniable that Islamic banking has been successfully implemented in the world today and it has gained the confidence of Muslims and nonMuslims alike. However, this does not mean that the number of Islamic banking products available in most local markets and even globally are diverse enough to cater for the need of poor members of the society. It is contemplated in this regard that if salam contract can be practically applied 
Muneeza \& Mustapha $\mid$ The Potential of Fintech in Enhancing The Use of Salam Contract in Islamic Banking

in Islamic banking, such poor people, who constitute the largest number of farmers in many societies, can be greatly helped thereby developing agriculture as an important segment of the real sector of the economy.

In salam contract, one of the objectives is generally to fulfil the needs of farmers and merchants who require money for farming and the production of agricultural produce as well as other fungible things. Usually, advance payment via salam for such produce enables acquisition of farming facilities and equipment by the farmers and to provide for their families till harvesting time. Salam contract also can be employed to assist traders in exports and imports trading. In salam for trading, traders would sell goods in advance to undertake their business with the cash price received. Here, salam appears to be beneficial and offers an advantage to both traders and buyers - the traders receive the sale price beforehand and the buyers pay a price that is usually below one to be paid in spot sales (Meezan Bank, 2019). Salam-based financing instruments have great potentials to bring about economic development. A simple illustration of salam and its impact on the economy is made by Abdul Rahman when he stated that: "This model is used to finance the cost of future production of a manufactured product or an orchard. The customer will agree with the Riba Free (RF) finance company to forward the cost of future production. The RF financial institution would come to an agreement to buy the production of an orchard, a farm or a manufactured product (like equipment or automobiles) before it is produced, at an agreed upon price. The money is paid in advance to the producer. The producer, in turn would use the money as a working capital to purchase the basic services, pay wages and buy raw materials necessary for the production. This way, RF financial institution would help in the growth of the economy by providing the liquidity needed by the producing entity" (Abdul Rahman, 2010; p.58).

Salam is one of the most least used and hence, researched contract in Islamic finance including Islamic banking. The main reason for the less frequent usage of this contract in Islamic finance is due to the high risk involved in the execution of the contract. In the era of fintech, there is potential to explore the ways in which the usage of salam contract could be increased. Since there is a gap in the literature in this regard, this research attempts to fill this gap by presenting the possible ways in which fintech could enhance the use of salam contracts in Islamic banking. So far none of the existing studies have attempted to do so and as such, this is a novel research that would pave way to begin research in this area.

\subsection{Objective}

In view of the foregoing, this research aims to study existing practices of salam application in Islamic banks' financing and how to employ emerging 
Muneeza \& Mustapha $\mid$ The Potential of Fintech in Enhancing The Use of Salam Contract in Islamic Banking

technologies to enhance it. The concept of salam has traditionally been associated with agricultural produce due to the fact that it is directly mentioned in a Hadith on a related case. However, since from buyer's point of view the process of production is not significant, then the distinction between agricultural production and industrial or manufacturing production is considered immaterial in applying the concept of salam in Islamic banking (Tahir, 2013).

This paper consists five parts. The first part is an introduction to the work that provides a background thereto as a stepping stone. Following the introductory part, the second part of the paper explores relevant literature to provide an overview of salam contract from Shariah perspective and/or under Islamic law. The third part of the paper deals with methodology while the fourth part discusses the results and analysis which is followed by conclusion and recommendation.

\section{Literature Review}

\subsection{Background Theory}

Salam or bai' salam is literally defined as "a sale or purchase of a deferred commodity for the present price (bay ajilin bi ajil)" (Ibn Abidin, 1996; p. 209; Amine, 2008; p.63; Kettel, 2011; p. 137). In its classical conception, a salam contract arises where contracting parties agree for a sale of goods for which immediate cash payment is made on executing the agreement but they would be delivered in future time (Aburaida, 2014; p.161; Amjad, 2015; p.42). For the purpose of Islamic banking, the Bank Negara Malaysia defines Salam contract as "an agreement whereby an Islamic banking institution purchases from an obligor a specified type of commodity, at a predetermined price, which is to be delivered on a specified future date in a specified quantity and quality" (Paragraph 2.73 of Capital Adequacy Framework for Islamic Banks (Risk-Weighted Assets), Bank Negara Malaysia, 2018). In this context, an Islamic bank will make payment of price in full at the execution of a salam contract and stand as a purchaser of a commodity to be produced. Salam is a Shariah contract whose permissibility is ordained in a passage of a hadith narration where Ibn 'Abbas (RA) recounted: "When the holy Prophet Muhammad (SAW) came to Madinah, people used to pay two or three years in advance for dates. He (the holy prophet) said:" "Whoever pays for anything in advance, let him pay for a specified measure and a specified weight, to be delivered at a specified time" (al-Bukhari, 2240 and Muslim, 1604). It was on these conditions that the Prophet (SAW) allowed the farmers to engage in salam. On this point, it should be noted 
Muneeza \& Mustapha $\mid$ The Potential of Fintech in Enhancing The Use of Salam Contract in Islamic Banking

that the general rules of Shariah applicable to sale contracts are that, at the time of sale, existence of subject matter must be ascertained and that same must be in seller's ownership. However, salam has a unique nature as a Shariah contract and takes an exception to these rules which allows for a leeway from the general rule (Ahmed, 2007).

The Prophet (SAW) permitted salam in order to provide ease for the farmers and traders in their dealings on the stated conditions. Although the premise of the permissibility of salam was originally in agriculture, the Islamic jurists have not confined its application to only agricultural goods as per the hadith mentioned above. Islamic jurists are unanimous that any goods that can be measured, weighed and/or ascertained by given specifications could be subject of salam as well. Accordingly, the list of 'salamable' items has been expanded by the jurists to include all goods or items precisely ascertainable by quality and quantity (Mansuri, 2006; p.201). Similarly, in all schools of Islamic law, strict Shariah rules and conditions are observed while engaging in a salam contract. Nonetheless, there are differences of opinion among Islamic jurists with respect to some aspects of salam in its practice.

Available literatures on Islamic finance are replete with discussions on salam as an Islamic financing concept, for the most part, in agricultural financing (Saiti, et.al., 2018; Hisham \& Jaffar, 2017; Dchieche \& Aboulaich, 2016; Ebrahim \& Rahman, 2005). Relevant literatures provide elucidation on the practice of salam contract in Islamic finance generally and in Islamic banking in particular, which is the perspective of this research. From a perspective, Islamic banking plays an integral role in the establishment and development of halal and Shariah compliant equivalent of industries that are imperative for the efficient operation of modern society. In this regard, the agriculture industry and often times manufacturing industry stand most critical. Bank financing of agriculture and or manufacturing is key to the commercial success of these industries as it is to all others (Saqib, 2011; Saqib et.al., 2014). Islamic banks financing via salam instrument has been identified by several authors (Utama, t.al., 2019; Ajmal, et.al., 2017; Kaleem \& Ahmad, 2016) as an important function that will play vital role in that regard. Therefore, Islamic banks need rethink financing for agriculture for the production of both non-crop and crop produce (Saqib, 2011). From another perspective, the manufacturing industry is a peculiar industry with regard to contract for goods ordered to be produced and or manufacture. This would include custom-built goods or merchandise of particular customized specifications. This is an area that salam instrument has been deployed by Islamic banks to cater for customers/clients demands in that respect (Ajmal, et.al., 2017; Yusoff \& Kamdari, 2016; Miah \& Suzuki, 2018). Asides being readily compatible with modern banking, salam is one instrument that offers added advantages over other instruments of Islamic banking like musharakah 
Muneeza \& Mustapha $\mid$ The Potential of Fintech in Enhancing The Use of Salam Contract in Islamic Banking

and bai bithaman ajil (BBA) when it comes to financing the agricultural sector of the economy (Kaleem \& Wajid, 2009). Despite these roles and benefits derivable therefrom however, salam contract remains largely under-utilized in Islamic banking as some studies established mainly due to a misconstrued notion about its viability and risk as a financing instrument (Hassan et.al., 2011; Suayb, 2008). This misconception has discounted the social value and usage as well as of salam among Islamic bank in many jurisdictions (Hassan et.al., 2011).

\subsection{Essential Conditions of Salam Contract}

Salam is conceptually meant to assist and provide financing for future products by purchasing such products through advance payment of sale price. As such, a buyer is required pay full price of the goods as agreed to at the sale, there and then. This is a fundamental requirement that prevents the transaction slipping into the forbidden transaction of sale of debt against debt (Razali, 2012). In the same vein, quantity, quality and other specifications of the goods subject of salam are required to be stated with certainty for the avoidance of ambiguity. This applies to place and delivery date as well although they can be mutually altered or adjusted. The subject matter of salam comprises of only those goods or items technically referred to as 'dhawatul-amthal'. These are items, whose units are homogenous in characteristics, i.e. they can be measured, weighed or counted while traded in accordance with applicable trade custom and usages. Thus, other products such as livestock and precious stones cannot be subject of salam. It is worthy of note that deferment of delivery is vital in salam; as such items that are by nature of spot transaction whose delivery is required to be simultaneous, cannot be subject of salam. Thus, exchange of silver with gold or rice with wheat for instance cannot be salam. Moreover, ownership of salam products cannot be validly transferred by buyer to any entity before taking actual or constructive of them. It should also be noted that salam and parallel salam are independent of each other and so no stipulation can be made in such a way that one is tied to the other as to affect respective obligations and rights arising from each of them. On the part of the bank, a security or collateral may be required in order to ensure the farmer(s) or seller(s) deliver salam goods as agreed. The bank can resort to disposing of such a security or take legal action in court against delay in delivery by the farmer or seller (Usmani, 1999; p. 129-131). In this case, the court may, on its own discretion, award damages to the bank which is to be determined based on direct and actual loss cost incurred by the bank. Alternatively, a penalty can be provided for in the salam agreement against such an event. For this purpose, it can be provided in the salam contract that the seller shall be liable to pay a penalty, 
Muneeza \& Mustapha $\mid$ The Potential of Fintech in Enhancing The Use of Salam Contract in Islamic Banking

to be calculated at a certain agreed rate. Regardless of such a provision in the contract, in the event that a penalty is realised from the seller due to delay in delivery, that penalty shall be used by the bank; it shall be separated from the bank's earnings and used for the purposes of charity only (Muneeza et.al., 2019; p.6-7).

\subsection{Practice of Salam and Parallel Salam in Islamic Banking}

Salam is such an adaptable instrument/product that can employed to support all classes of farmers as well as craftsmen or traders in the society, especially the poor ones or those with little or no capital. However, for Islamic banking practice, parties to be provided with salam financing include legal persons or corporate bodies besides natural persons. As an instance, an Islamic bank may be approached by a farmer and expresses desire for financing and selling the produce to be realised from the financing. The bank will analyse the farmer's credibility and may accept to buy the farmer's produce to be produced at a specified future time and agree to provide the sale price for financing the production. The price, quantity, quality and delivery time would be negotiated and determined. Thereafter, a salam agreement would be sealed. The bank pays the full sale price on the spot and in cash upon sealing the salam agreement. At the agreed date, the farmer delivers the products in accordance with the agreement and that completes and concludes the salam contract. The bank then sells the products at a different price to any interested buyer and the margin in the selling price is going to be the profit for the bank (Al-Zaabi, 2010). A risk for the bank here is where the bank could not find a buyer and/or the products need to be stored which means additional cost against the bank. It may be that the bank does not have storage facilities, or the goods are perishable and could deteriorate with storage.

In order to avoid the likely event of not finding a buyer and its attendant risks, a type of salam has been devised for that purpose. Known as a 'parallel salam', it is a kind of contract whereby an Islamic bank would, after sealing a salam contract with a farmer as in the above instance, enter a separate sale agreement with a buyer through wa'ad. Wa'ad signifies a willing promise to purchase the products immediately they are delivered to the bank by the farmer (Kurniawansyah \& Agustia, 2017). In this way, the bank is saved the risk of loss. This kind of salam mitigates a risk of the bank in the operation of salam as it does away with the need of storage for the products. Nonetheless, there is another risk for the bank to contend with where the farmer defaults in delivering the products at the specified time as the buyer may take legal action against the bank for breach of agreement. It is a 
Muneeza \& Mustapha $\mid$ The Potential of Fintech in Enhancing The Use of Salam Contract in Islamic Banking

condition of validity in parallel salam for the bank to negotiate two different and independent contracts, one with the farmer that receives financing via advance payment of sale price and the other one with a third party (Mansuri, 2006). Similarly, buy-back is not allowed in salam as it is only permissible with a third party. The position of this rule equally remains even where the parallel salam involves a distinct legal person i.e. a company but is owned by the seller in the first salam. Thus, the seller(s) or farmers(s), including their subsidiaries, in the salam contract can never be the buyer(s) under a parallel salam. Nevertheless, the seller(s) and the buyer(s) can enter into a separate sale transaction on their own free accord after the delivery of the subject matter which completes the salam. See figure 1 below for illustration.

There are several risks associated with salam which constitute the reason Islamic banks in many jurisdictions are disinclined to employing it as a financing product (Sundararajan, 2013; Izhar \& Hassan, 2013). These risks comprise among others delivery and counterparty risk, marketing risk, price risk, asset-holding risk and risk of early or premature termination. However, as a versatile commercial engagement tool and couple with the popular principle of business that liability or risk is associated with every gain, salam should be treated like any other business instrument. It is also common in the commercial context that risk taking decision always comes at a cost. Besides, it takes regular and common prudence in addition to managerial skills to mitigate the risks associated with salam (Muneeza et.al., 2011; Ayub, 2007).

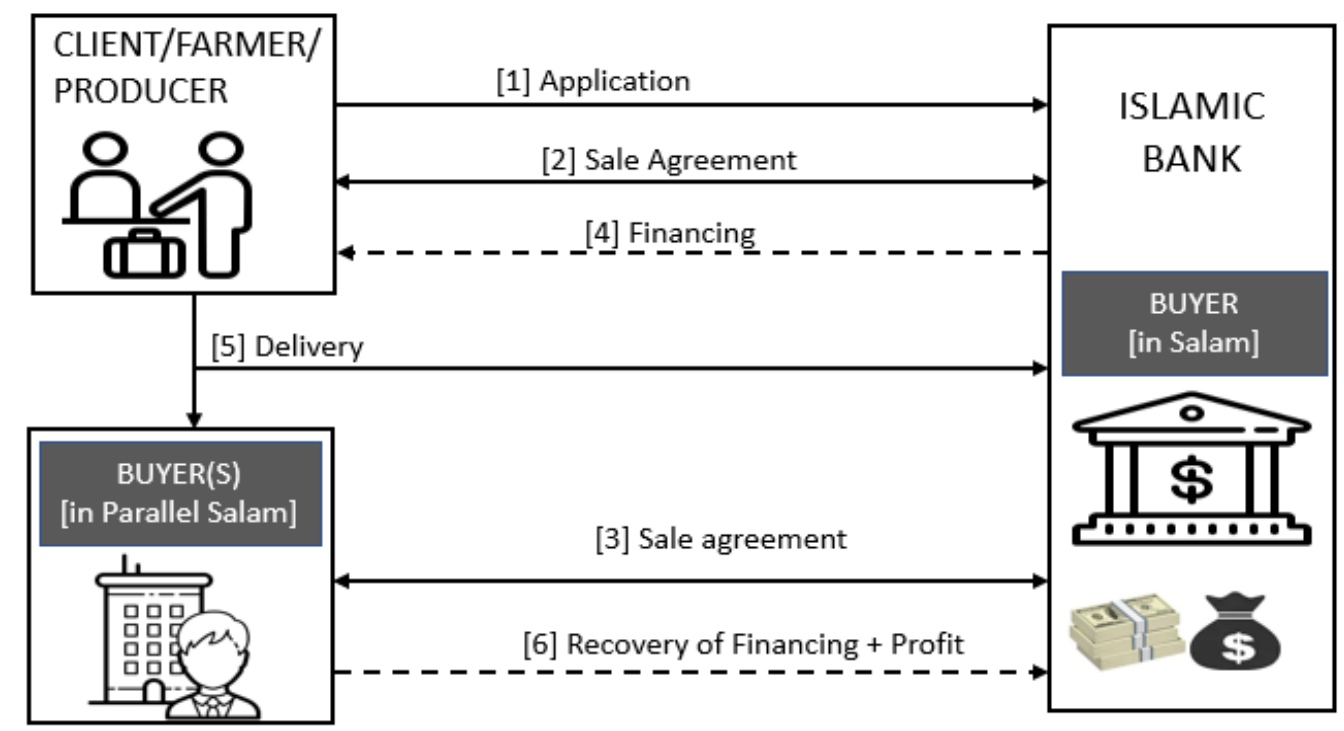

Figure 1. Salam and Parallel Salam Transaction Source: Author's own 
Muneeza \& Mustapha $\mid$ The Potential of Fintech in Enhancing The Use of Salam Contract in Islamic Banking

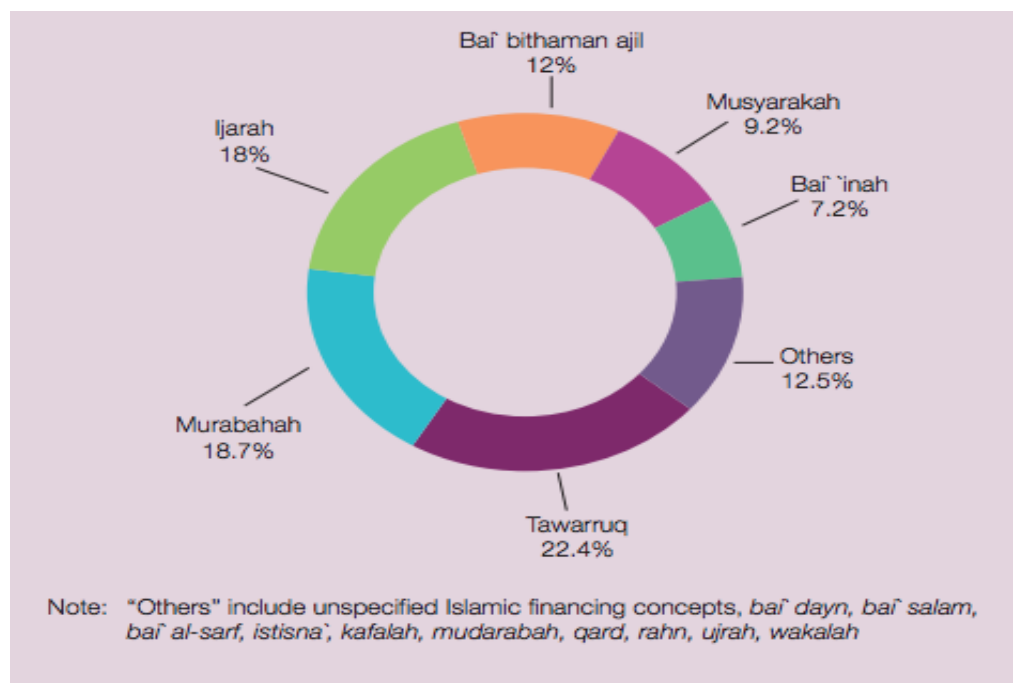

Figure 2. Composition of Financing by Shariah Contracts in Malaysia Source: Bank Negara Malaysia (2016)

The use of salam contract in Islamic banking varies from jurisdiction to jurisdiction. For example, the product composition of Islamic finance contracts in Malaysia illustrated in Figure 2 below illustrates that Salam contract is not widespread in Malaysia. However, in jurisdictions like Pakistan and UAE, salam contract is used by Islamic banks for financing.

Figure 2 (above) states that all other unspecified Islamic financing concepts which compose of bai' dayn, bai' salam, bai' sarf, istisna, kafalah, mudarabah, qard, rahn, ujrah and wakalah contracts constitute only 12.5 percent of the total financing via Shariah contracts. This indicates the negligible usage of salam contract in Islamic financing in general and particularly its non-usage by Islamic banks in Malaysia. Regardless of this fact, salam contract comes both handy and relevant in Islamic banking for the following factors. Firstly, a separate murabahah may be impracticable to use for all procurements in Islamic bank financing. Secondly, using profit and loss sharing (PLS) as an option is supposedly imprudent for being not so compatible with all clients' needs or modes of production and procurements among other reasons. Thirdly, there are standardized outputs resulting from production activity for which there are willing buyers and suppliers (Tahir, 2013). Salam contract can thus be used to finance industrial activities that can be compatible with the nature of salam transaction such as production of sugar, automobile, textile, cement, paper and similar goods. Salam contract offers a lot of benefits for and is quite invaluable in agricultural sector financing for crops and non-crop production by large-scale industrial farmers, as well as wholesale and export trades financing. In addition, salam financing is equally practicable and compatible with project financing in addition to fixed assets financing needs of industries among other sectors of economy (Harran, et al., 
Muneeza \& Mustapha $\mid$ The Potential of Fintech in Enhancing The Use of Salam Contract in Islamic Banking

2010). Salam instrument can accordingly be applied wherever advance payment with client in terms of output to be produced is not only compatible but practicable and beneficial. Furthermore, salam stands as a better means of providing personal financing for local individual farmers who are predominantly poor and yet constitute the largest number in this respect. In view of the potential areas where salam contract can be employed in Islamic banking, it is observable that salam is used for different financing purposes in different Islamic finance jurisdictions across the world. Below are some examples of salam instruments and/or products that are developed and practiced in different countries.

\subsubsection{Pakistan: Salam Based Model for Shipping of Goods-Currency-based Salam Transaction (Usmani, 2019)}

A currency-based salam is used for the purpose of shipping goods for export in accordance with contract terms constituted by a Letter of Credit (LC). Here, the exporters need not wait to receive payment at a future date for the shipping made to a foreign country. The exporters get cash in local currency as payment by getting the relevant bill of exchange 'discounted' at and against an Islamic bank via the currency-based salam. Muslim jurists hold divergent views on this. According to imam Maliki and adherent scholars, salam is not sanctioned to be executed in fuloos due to fact that Sarf ruling is applicable to it and taking possession on both counter values is a precondition thereto. To Imam Ahmad bin Hanbal however, executing salam on fuloos is authorised provided the ras ul maal comes in form of goods since, as a rule, verdicts of Sarf are not generally applicable to fuloos. More so, fuloos are not thaman genetically, so execution of salam thereon is considered lawful. In addition, as Ahnaf is reported to have narrated, while Sarf ruling is not applicable on fuloos, executing salam in numbers is only legitimate where the fuloos are traded against one another. The transaction will however be illegitimate where both counter values are homogeneous. This is because it is a precondition in this case that possession is taken on both counter values while it is not the case in salam contract. So, given that they are traded against their opposing genus then it is a prerequisite that one single value be taken possession of, and it will be legitimate howsoever excessive. The process involves the Islamic bank purchasing on a market rate the foreign currency from the exporters, which will be transferred at an agreed date, for the instant payment made to them in the local currency. Thus, while the exporters receive the local currency instantly, it remains a liability on them to be settled by paying the foreign currency to the Islamic bank when received at the agreed date. This process flow is summarized in Figure 3 below. 
Muneeza \& Mustapha $\mid$ The Potential of Fintech in Enhancing The Use of Salam Contract in Islamic Banking

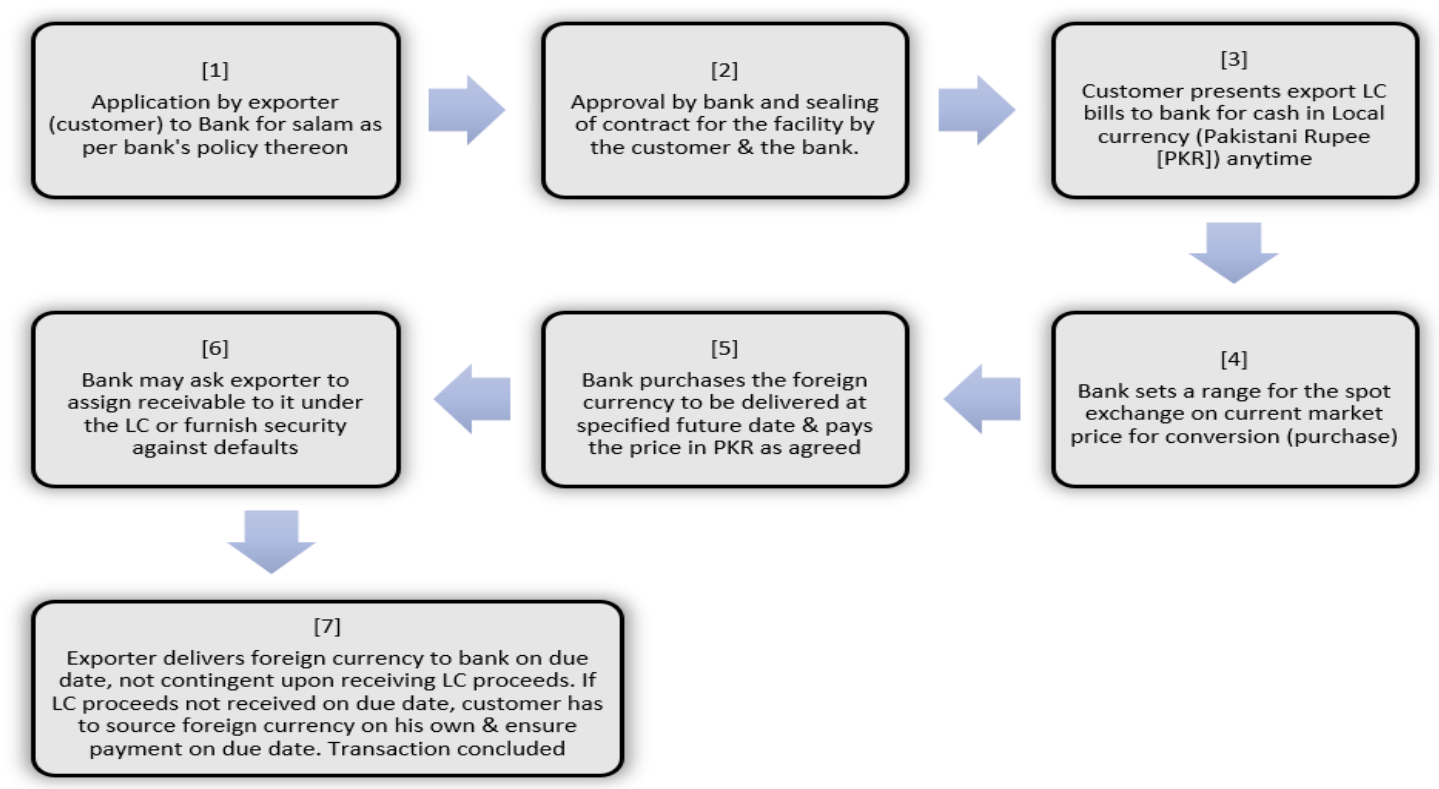

Figure 3. Process Flow of Currency based Salam Source: Author's own

Sindh Bank Limited of Pakistan uses salam contract as a mode of financing with an option for bill discounting in the sense it is used by conventional banks. Usually after shipping goods, exporters are normally disinclined to hold on for the LC proceeds which come at a future date. They bring the export documents to a conventional bank's counter and get them discounted or get equivalent of the LC proceeds in local currency at a discount. However, bill discounting is not permissible by Shariah. A such, Sindh Bank uses an alternative of Export Sight Bill Discounting based on Salam. In this transaction, the bank purchases the foreign currency from the exporter and effect instant payment in Pakistani Rupees (PKR).

In relation to the foregoing and as a regulatory backing thereof, State Bank of Pakistan's Circular No. 02 of 2014 entitled "Shariah Compliant Solutions for Foreign Bill Discounting" states that "the Salam of foreign currency is not a preferred transaction, however if some IBIs are interested in doing this transaction, the same shall be executed at the market rate of the day. For the purpose of such transactions, the market rate shall mean the exchange rate used to carry out normal ready transactions of at least USD 50,000 or more by the IBI with its clients. Further, the IBI's Shariah Advisor (Shariah Boards from 1st Oct. 2014) shall ensure, through regular reviews that the exchange rate(s) applied in currency Salam transactions of any day are/is not different in any material way from the exchange rate(s) applied for ready transactions of USD 50,000 or more executed by the IBI during that day" (State Bank of Pakistan, 2014). 
Muneeza \& Mustapha $\mid$ The Potential of Fintech in Enhancing The Use of Salam Contract in Islamic Banking

\subsubsection{Pakistan: Salam Based Financing for Farm/Crop Production Purposes}

The State Bank of Pakistan has issued guidelines titled as the Manual for Salam Based Financing for farm/crop Production Purpose (State Bank of Pakistan, 2011; hereinafter referred to as the Manual). The Manual states that "the farmers at their discretion may enter into single or multiple salam transactions based on their specific funding needs. Under single salam the total funds needed by the farmer will be disbursed/credited to the farmer's account in lump sum. Whereas, under the multiple salam transactions the funds would be disbursed in tranches as and when needed by the farmer by executing various/multiple salam. However, the farmer would have the option to choose the single or multiple Salam depending upon his/her convenience and preference" (Paragraph 1.1 of the Manual). Under the manual, all farmers are qualified to get salam financing from an Islamic Banking Institutions (IBIs) (Paragraph 1.2 of the Manual). Banks are required to undertake an objective and thorough assessment of farmers financing needs and expected production in a salam transaction (Paragraph 1.3 of the Manual). An average of 1 to 3 years market value is to be allowed while purchasing from the farmer whose produce shall be purchased by not less than $75 \%$ of total production (Paragraph 1.4 of the Manual).

The procedure or process flow for the transaction involves an initial execution of a master salam agreement, among other documents, based on a memorandum of understanding (MOU) which prescribes the framework for individual Salam contract. The agreement details the parties' obligations and rights as well as the specifications of the produce. At the execution of the contract, the bank pays the sale price to the farmer who at maturity delivers the produce or commodity to the bank (Paragraph 2.1 of the Manual). An Islamic bank under the manual may secure its financing via security or collateral from the farmer which may include charge on land, mortgage of property, hypothecation of assets such as machinery and even lien on deposited money or liquid security such as gold etc. with the bank. Alternatively, an individual or group or corporate guarantee is acceptable (Paragraph 2.2 of the Manual). There are provisions for parallel salam as well for the bank (1 Paragraph 3.2 of the Manual). To ensure safeguarding the interests of both the bank and farmer, the manual requires crop takaful/insurance (Paragraph 4.1 of the Manual). The salam financing matures per cropping cycle but can be provided usually for a period of 6 to 8 months. An exception is made with respect sugarcane whose period of financing can go up to 18 months (Paragraph 3.3 of the Manual). 
Muneeza \& Mustapha $\mid$ The Potential of Fintech in Enhancing The Use of Salam Contract in Islamic Banking

\subsubsection{Sudan: Salam for Financing of Agricultural Goods}

Al-Barakah bank of Sudan practices salam for providing financing for farmers. As stated in the bank's official website (AlBaraka Bank, n.d.), "Sale of salam are good for agricultural operations. The bank directly deals with farmers who expect good production of a certain commodity or, in case the production is not good enough, can obtain same commodity from other farmers to settle bank debts." In this product, the customer makes an application to the bank offering for sale certain commodity providing detailed description of the commodity, its quantity and price. The customer expresses willingness for and guarantees delivering the commodity to a specified place at a later date. Thereafter, the bank meticulously examines the application and if it is satisfied of its seriousness, then fixes its own suitable conditions as well and guarantees approving finance. Afterward, the bank and the customer execute the salam contract and the bank and pays the amount agreed immediately. At the agreed later date, delivery of the commodity would be made to the bank by the customer in accordance with the salam agreement and completes the transaction.

\subsubsection{United Arab Emirates (UAE) - Salam for Personal Financing}

As the world's first Islamic bank, Dubai Islamic Bank (DIB) has developed an Islamic financing service for personal liquidity solution, tagged 'Al Islami Salam Finance', based on salam contract. Al Islami Salam Finance provides a whole suite of personal as well as corporate and business finance solutions. Structure for personal liquidity solution as used by the DIB was initially proposed by a leading contemporary Shariah scholar in the person of Dr. Hussein Hamid Hassan who had used the salam structure for certain corporate deals (Global Islamic Finance Report, 2011). During those deals, he understood that if this product was to be practiced in Islamic banking, then challenges associated with documentation, delivery, storage, etc., which are encountered in satisfying Shariah requirements would be overcome. Dr. Hussein invented a structure that offers suitable solutions for the abovementioned glitches in Islamic banking.

To gain wider acceptability, Dr. Hussein presented the proposed structure in the meeting of the Unified Shariah Committee of the UAE, an umbrella body of Shariah scholars from all Islamic banks and other financial institutions in the country. The Committee objected to the proposition to use metal of the London Metal Exchange (LME) as the subject matter of the salam sale. This is because it is not possible for the parties in salam to be in actual possession and direct control of the commodities. It is remarkable to observe in this 
Muneeza \& Mustapha $\mid$ The Potential of Fintech in Enhancing The Use of Salam Contract in Islamic Banking

regard that using commodities for tawarruq model is allowed, and the transactions therein (sale and purchase) are, on constructive possession basis, regarded as Shariah compliant. In addition, the element of agency in the structure was also objected to, although it forms an important part of tawarruq. Eventually the Committee agreed to guidelines removing the agency and LME-based commodities in the structure.

Basically, this structure involves a salam sale between the bank customer (seller) and the bank (buyer) based on the usual obligations and rules governing salam sale. However, in order to make sure the customer is capable of effecting delivery at due date under the structure, the customer is obliged to get a sale undertaking given out by provider of the salam commodity to the effect that the provider undertakes to offer the commodity for sale to the customer immediately the customer requires him to sell based on a pre-arranged price. At each agreed delivery date, the customer buys the commodity from that provider and sends same to the bank. The bank on its part usually secures a purchase undertaking from a broker (different from the commodity provider) to ensure it is capable of disposing the commodity upon receipt. The broker buys the commodity in accordance with a schedule that tallies with dates of delivery in the main sale undertaking given out by the provider. This is for the bank to ensure it is capable of disposing the commodity upon receipt. This arrangement guarantees the bank instantly disposes the commodity on its part (Global Islamic Finance Report, 2011; p.52).

The Dubai Islamic Bank has removed the agency element and LME from the structure it uses in providing salam-based cash financing product to retail customers. In addition, DIB uses any commodity obtainable locally with the aim that both the bank and the customer are not only capable of taking actual possession but also exercising control over the commodity. In this regard, the DIB largely uses refined sugar as the subject matter due to the fact that raw sugar is brought into the country in millions of tons and sold to distributors after refinement.

Abu Dhabi Commercial Bank (ADCB) also uses salam for personal financing. The modus operandi of this product is explained in the official website as provided in Figure 4 below. 
Muneeza \& Mustapha $\mid$ The Potential of Fintech in Enhancing The Use of Salam Contract in Islamic Banking

National Bank of Ras Al Khaimah (RAKBANK) UAE also uses salam to provide personal financing. On 2nd May 2012, the Shariah Supervisory Board of RAKBANK has approved the following product structure based on salam for personal financing. The approved process flow is illustrated in Figure 5 below.

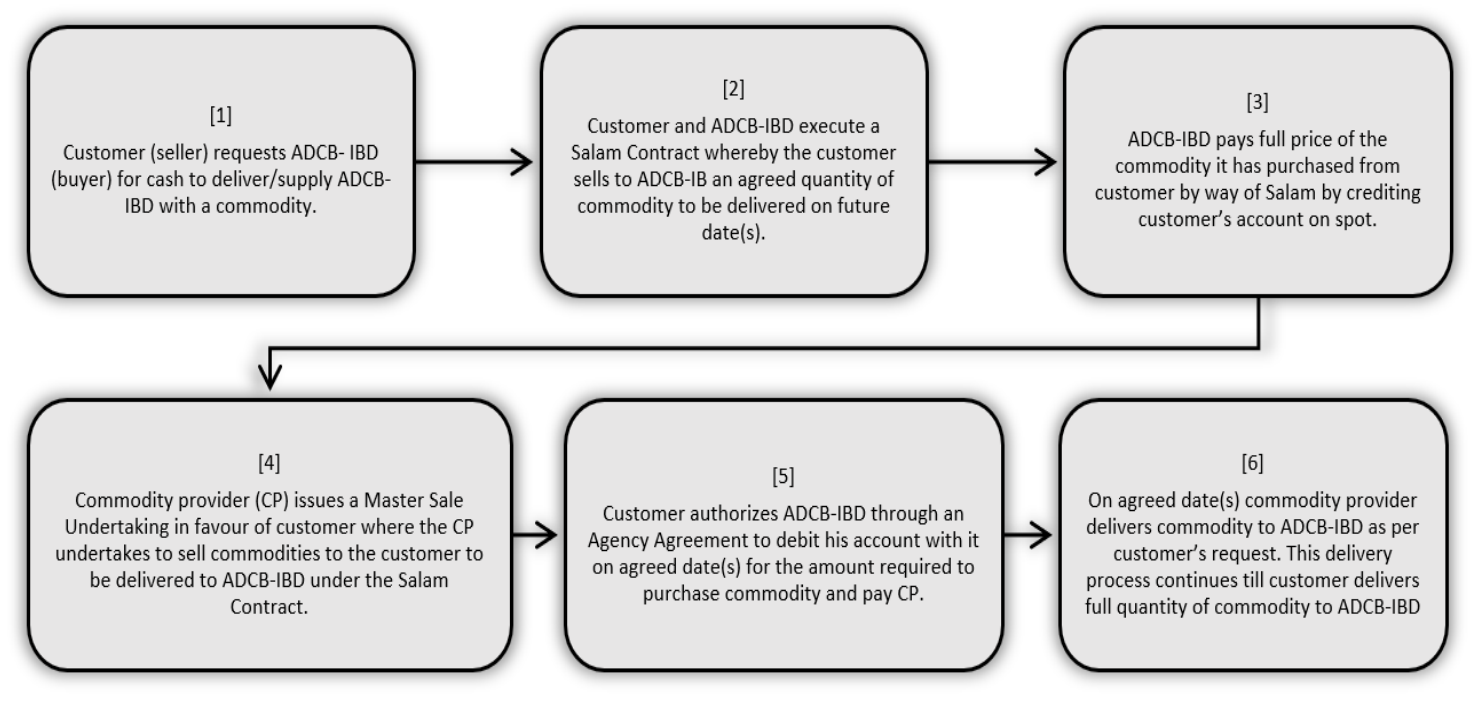

Figure 4. Modus Operandi of ADCB Bank's Salam Personal Financing Product Source: Author's own

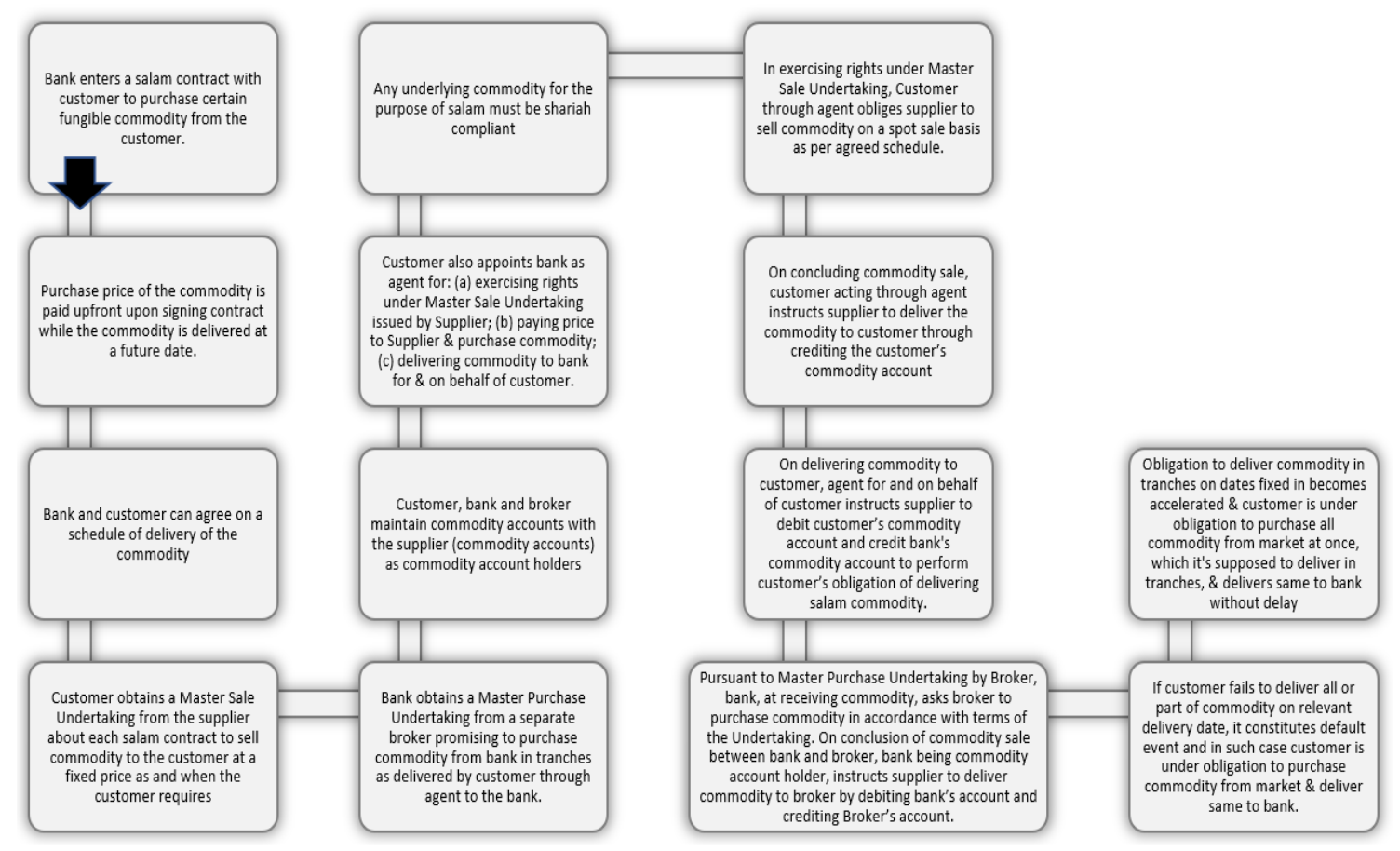

Figure 5. Process Flow of Salam-based Personal Financing for RAKBANK Source: Author's own 
Muneeza \& Mustapha $\mid$ The Potential of Fintech in Enhancing The Use of Salam Contract in Islamic Banking

Salam as used for personal financing is termed organized salam (Abozaid, 2010). It is argued that that the profit received from personal financing cannot be considered as earnings for Islamic banks as it goes against the injunction prohibiting riba (usury/interest) in Shariah. It is observed that these types of personal products of Islamic banks have been materialized only in an effort to imitate products of conventional banking. In contrast however, this kind of financing does not match the recognized Shariah contracts for sale of usufructs or goods such as ljarah, Istisna', Murabahah, etc. Moreover, where customers demand financing for services, goods and usufructs, Islamic banks can finance them only through the appropriate Shariah contracts. It is obvious in this regard, as Abozaid maintained, that in practice executing a sale contract in organized Tawarruq and Salam is done only on paper short of any realistic impact on the goods, not even at least a change of place or movement symbolic of such a sale. Thus, as it is generally known, goods sold only on paper are subject of an invalid sale. This is coupled with the fact that all parties involved including the client, customer or the broker and the Islamic banks are fully aware that the goods are supposedly contemplated in this process for the single reason of releasing money by the bank to the client who returns same to the bank with an increase. The goods would not in any way be impacted upon as no effect of sale whatsoever is intended in that regard. Regardless of the fact that some scholars view and claim otherwise about this process, it is an obvious fact that the overall transaction flow and or process is such that it makes possible earning returns on cash advancing or cash financing alone which all parties know from initiation of the contract. In this regard, it is accordingly maintained that Islamic finance approves of cash financing for individuals or institutions through no other means except Qard (Kahf \& Mohamed, 2017).

\section{Methodology}

A qualitative methodology, drawn on content analysis, is employed in conducting this research. This approach generally encompasses examination and qualitative interpretation of documented data from primary as well as secondary sources to arrive at conclusion (Beer and Faulkner, 2014; Mayer, 2015). From both sources, non-empirical data on current application and practice of salam contract alongside its theoretical underpinnings was examined in this research. Accordingly, data analysed in this research were obtained mainly from texts of documents catalogued in libraries (INCEIF and University of Malaya) as well as online academic databases including Scopus, Web of Science, LexisNexis, HeinOnline, EBSCO, Google Scholar among other 
Muneeza \& Mustapha $\mid$ The Potential of Fintech in Enhancing The Use of Salam Contract in Islamic Banking

internet resources (Chermack and Passmore, 2005; Hutchinson, 2015). Thus, as a research in Shariah contract, the primary sources examined in this regard comprised of prophetic hadith and Islamic banking regulatory provisions on salam. The secondary data sources consulted include journal articles, books, conference papers, magazines and salam product documents of some Shariah banks which specifically provide description and information on practical application of salam in Islamic banking and general use of technology to deliver financial services (Webley, 2010; Onwuegbuzie et al., 2010; Moser et al., 2018). Through content analysis, text of information solely from the identified data sources were systematically studied and analysed without employing any statistics (Cownie and Bradney, 2013; Drisko and Maschi, 2016, pp. 81-82). Through this process, not only obvious substance on Islamic banking and fintech were addressed but also core ideas and themes relevant for technology-based application of salam contract in Islamic banking, upon which proposal for enhancement was proffered including the recommendation and conclusion of the entire research.

\section{Results and Analysis}

\subsection{Results}

The advent of Industrial Revolution 4.0 has seen the emergence and development of technologies that today play an essential role in human activities with improvement in human lives. Prominent among the technologies in this regard include blockchain technology, internet of things (IoT), artificial intelligence, robotics among others.

Blockchain is an automated system of generating and keeping transactions record, monetary and otherwise, in form of blocks that are linked to each other as a chain by cryptography and operates as a distributed or decentralized public or private digital ledger (Pilkington, 2016; Yu, et al., 2017). A distributed ledger in this context, largely typified by the blockchain, is a consensus mechanism that entails replication, sharing and synchronization of digital data dispersed across multiple locations or sites without any centralized pivot or administrator (Skwarek, 2019; p.162). By decentralization, it means the transactions are recorded across numerous computers that render it impossible to retroactively alter the record unless all subsequent blocks in the chain are accordingly altered i.e. alteration cannot be done without consensus of the blockchain network comprising of computers called nodes. At the same time, a consensus algorithm of the blockchain network enables making and addition of new transaction blocks into existing blocks to form a continuous chain of blocks. Therefore, using 
Muneeza \& Mustapha $\mid$ The Potential of Fintech in Enhancing The Use of Salam Contract in Islamic Banking

specified algorithm, each block in the chain is designed in such a way that its data record is resiliently unmodifiable and carries a cryptographic hash of the block before it, a timestamp and dataset of the transaction (Zheng, et.al., 2017).

From its conception, the blockchain technology is utilized for the digital currency bitcoin (Nakamoto, 2008). However, with subsequent development from its earliest features, the blockchain technology comes to be a universal platform for creating digital assets and smart contracts that enable automation of other numerous transactions, financial and otherwise (Tapscott \& Tapscott, 2016; Babkin, et.al., 2019). With automation via smart contract algorithm, the blockchain has accordingly operationalised a concept of 'trustless' world where parties can conduct transactions with one another that hitherto required trust or personal knowledge between parties concerned. Everything therein operates without human involvement, but a series of incorruptibly programmed rules. That said, the blockchain technology thus keeps parties that are strangers to one another, honest and consistent in any transaction and tracking such transactions based on digital trust, without having to know one another (Calcaterra \& Kaal, 2020; Giancaspro, 2017). According to Szabo, the smart contract in its original coinage is "a set of promises, specified in digital form, including protocols within which the parties perform on these promises" (Szabo, 1996; p.2). Moreover, same protocol can be employed to incorporate contracts of all types of properties by digital means. In this way, smart contracts operate as the protocols deployed on and secured by blockchain that digitally authenticate and execute the contracts between or among contracting parties (Mendi, et.al., 2019; Hoffmann \& Skwarek, 2019). In other word, the smart contract basically encompasses a series of self-executing codes stored in the blockchain that effect particular operation when certain conditions and or predetermined terms are met (Wang, 2019). Smart contracts typically enforce certain encoded agreements that are established on blockchain platform to bring about automation of salam transactions. By and large, transactions embedded onto blockchain are encoded via specified smart contract algorithm with traceability and auditability functions. The blockchain and related technologies have so far found application, even though at infancy stage, in virtually all industries such as healthcare, finance, insurance, logistics and agriculture, besides plans to introduce and adopt same by many others in the nearby future (Sonnenfeld, 2019). For the most part, smart contract cryptography features as an important aspect of blockchain automation and digitization (Peters \& Panayi, 2016; Christidis \& Devetsikiotis, 2016).

Internet of things or loT as it is commonly shortened refers to connectivity of objects with a network (the internet) for exchange of information and 
Muneeza \& Mustapha $\mid$ The Potential of Fintech in Enhancing The Use of Salam Contract in Islamic Banking

communication. IOT has enabled the interconnectivity of billions of devices often described as smart objects that proficiently collect information or data and communicate same with other systems that are on the internet. IOTbased devices or applications have been developed and enabled for use to operate, control and monitor variety of domain including process, smart cities, smart homes, smart phones, smart farming and such other systems usually tagged 'smart' in related context (Awan, et.al., 2019). Such IoT devices or applications are normally empowered by artificial intelligence and machine learning to generate information that is saved on blockchain to support farmers make decision timely. Smart farming is an emerging farming model that refers to management of farms using blockchain-compatible technologies comprising of IoT, artificial intelligence (Al), machine learning, robotics, drones among others to monitor operations and boost quality as well as quantity of products while optimizing the human labour needed for production (Sciforce, 2019). It is a synergy of blockchain, IoT and artificial intelligence that results in the all-important outcome of smart farming where operations are automated and monitored from cultivation and irrigation (including weather and soil conditions) to harvesting, storage and sale of crops. Mobile computing can be employed by farmers to access data stored by means cloud computing for monitoring and controlling activities in the farm. Cloud computing entails the deployment of computer or any information technology (IT) infrastructure based on the internet for providing services and platforms for managing, sharing and storing data or any resources (Banerjee, 2019; Awan, et.al., 2019). In this regard, mobile phones, hand-held devices and/or computers and related gadgets serve as the farmers' machines and interface on their own end for the control and monitoring of their farms (Sciforce, 2019).

\subsection{Analysis}

In this part of the paper, discussion is presented on possible roles that can be played by such technologies as blockchain and IOT among other related technologies for the enhancement of salam transactions. Blockchain technology can have a wide scope of application in Islamic banking to enhance salam contract and make it an innovative yet profitable product. From the onset, the blockchain can used in order to digitize salam operations and automate business/farming activities the subject of the salam. Digitization will bring about convergence of processes and technologies including blockchain, artificial intelligence, internet of things and machine learning to render salam operations effortless via automation. In this convergence, blockchain technology stands as the enabler as well as a platform that enables the automation (Shaun Crawford, et.al., 2019). Thus, 
Muneeza \& Mustapha $\mid$ The Potential of Fintech in Enhancing The Use of Salam Contract in Islamic Banking

salam can be automated with digitization based on blockchain, IOT and artificial intelligence. This way salam can be enhanced by addressing issues related thereto and improving it from the perspectives of both the banks and clients.

For the Islamic banks in particular, blockchain can offer a panacea where parallel salam contract could be eliminated in the process so that salam can be executed using a single contract. A critical reason why parallel salam is being used in agricultural goods for instance, is to mitigate operational risk of storing delivered agricultural goods and to ensure that all goods received by the banks will be fully sold. With blockchain's traceability and auditability functions, the banks would only need to ensure a ready market for the agricultural products by engaging with buyer(s) that require the goods preparatory to partaking in a blockchain-based salam contract. This would require the banks to be familiar with the market for the agricultural goods concerned and understand its pricing economics in order to market them. In this regard, the banks would need to promote the goods to interested buyers among its clients and the relevant industry for the goods. The banks can sell the goods/products directly via standing order to households and industries including corporations, enterprises, restaurants and related businesses and get them efficiently distributed by logistics firms. Involvement of logistics firm(s) for haulage and distribution supports salam and professionally facilitates selling the goods to all categories of buyers who can pay for them either in advance or at delivery at the due time. Accordingly, the banks would engage logistics company for haulage and distribution of the goods upon delivery by the farmers or producers at due time.

These processes may involve cost to the banks which may as well be recovered from the sale of the goods eventually. As a principle of Shariah, Islamic banks are not out to make profit and cater for themselves alone. They have higher objective of ensuring societal welfare. The additional costs in this case is to facilitate and sustain salam transaction which may likely involve poor farmers of the society. The costs may be considered part of the banks' societal welfare objective in helping such people to earn a living in this way. In addition, there is risk on the part of the farmers due to certain factors including unreliable rainy season and crop diseases/pests among other misfortunes which may affect production. These can be addressed with the development of blockchain's smart contract enhanced via artificial intelligence, IOT and related technologies to assist farmers establish a sustainable smart farming. This can mitigate the risk of failure to produce required goods to a large extent by detecting and preventing such misfortunes. Additionally, farmers/producers can have crop insurance (takaful). The insurance for this purpose is digitized and automated, whereby farmers can claim and get benefits automatically from the insurance firm 
Muneeza \& Mustapha $\mid$ The Potential of Fintech in Enhancing The Use of Salam Contract in Islamic Banking

which is on the same technologically operated platform as the farmers through the BloT. This insurance would credibly support the practice and enhance profitability of salam.

Accordingly, within an all-encompassing blockchain-based loT ecosystem, all parties can monitor and keep track of the salam goods or subject matter to be produced. In addition, clients or buyers (actual and potential) as well as other stakeholders including logistics firm on the part of the banks and insurance company on the part of the farmers/producers, are aware of the products' progress and keep up with its development up to its due time. The parties, including buyers and all stakeholders, are integrated into the blockchain-based loT ecosystem via user applications on smart devices. The smart devices, usually mobile, provide user interfaces or dashboards that enables all involved in any of the processes, to login into and interact with the system and maintain access thereto, on real time with mutual control access. The synergy of blockchain and internet of things works credibly well and this is illustrated in Figure 6 below.

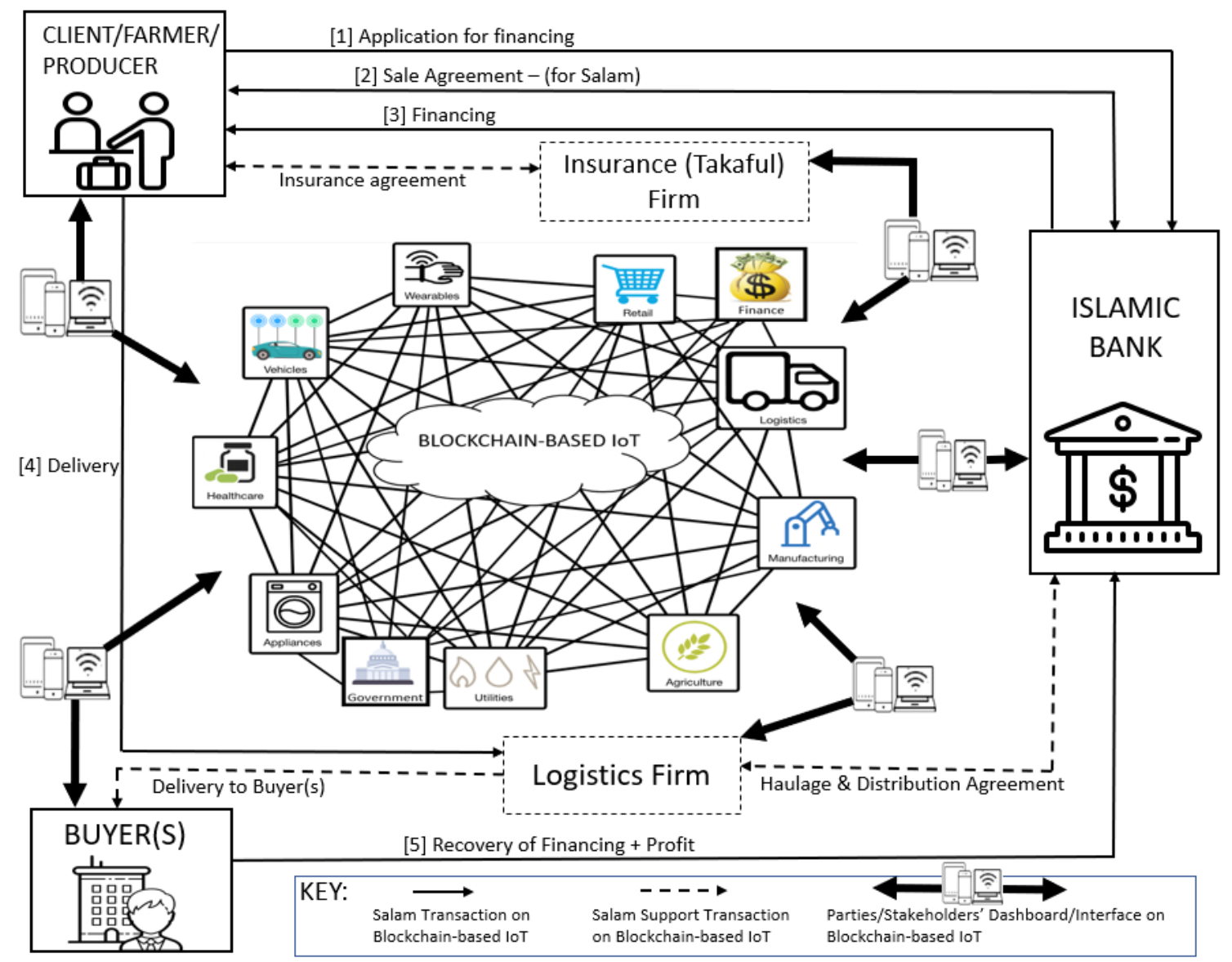

Figure 6. Illustration of Salam on Blockchain-based loT Source: Author's own 
Muneeza \& Mustapha $\mid$ The Potential of Fintech in Enhancing The Use of Salam Contract in Islamic Banking

\section{Conclusion and Recommendation}

\subsection{Conclusion}

Bai salam is one of the Islamic finance contracts currently used by Islamic banks for different financing purposes in several countries. In many others however, the banks are disinclined to employing salam in their financing services for its obvious associated risks. Regardless, this research has established that financial products developed from salam contract are viable, vibrant and innovative. Hence, Islamic banks that do not provide salam can learn and appreciate its practice by the banks that provide such financing services. In this regard, the practices and use cases of salam by Islamic banks in the UAE, Sudan and Pakistan are good models to adopt. In the UAE, salam contract is used as an alternative for tawarruq or commodity murabahah to meet personal financing needs of customers. It is nevertheless cautiously maintained that salam is not to be used for personal or cash financing; the permitted alternative and the best for that purpose is Qard. In Sudan, salam is used for financing agricultural goods. Meanwhile in Pakistan, there is salam-based model for shipping of goods (or currency-based salam financing) as well as salam for financing farm/crop production. These jurisdictions have provided use cases on salam financing that stand as model for products development of similar purposes where required.

\subsection{Recommendation}

The advent of blockchain technologies, IOT and their application in salam contract operations can enhance the operation of salam. The working of these technologies can do away with the risks associated with salam such as lack guarantee, uncertainty in or late, delivery, additional cost on storage etc. On the whole, digitization and automation of salam instruments and transactions thereon can bring about tremendous enhancements in all aspects of salam-based agricultural supply chain activities and export/import business. These enhancements are in turn beneficial to all parties including the Islamic bank, farmers, distributors (transportation), retailers and even consumers. Benefits to be derived in this regard include saving transaction cost and time, ease and certainty of processes, safety and security of goods subject of salam, support to small farmers, prevention/reduction of waste of produce, better supervision and management of supply chain. By and large, this research demonstrates that a technologically enhanced salam transaction is possible and can be used to structure Shariah compliant products for Islamic bank financing. Such products can accordingly be developed and tailored to meet the need of clients in any particular society. 
Muneeza \& Mustapha $\mid$ The Potential of Fintech in Enhancing The Use of Salam Contract in Islamic Banking

It is thus expected that the research will motivate Islamic banks in countries that do not practice salam to learn from those Islamic banks in jurisdictions that practice salam and adopt salam contract to structure products for their respective use cases.

It is important to reiterate however, that the broad range of activities to be taking on the blockchain and loT for the operation of salam are no more than a showcase of the possible areas in which stakeholders can venture into in pursuit of innovation. The research envisions the working of a technologically-based salam and demonstrate how to go about it. As robust as the synergy of blockchain and loT is demonstrated to be, no use case is known to the authors at the moment, and so at best it is futuristic. In essence, the blockchain and related technologies are emerging projects in an early development phase. Researches are ongoing on key areas pertaining to vulnerability, security and privacy to be improved and practicalized to attain desired security, scalability and decentralisation of the ecosystem as it is often characterised. Despite its immutability, auditability, incorruptibility features and the all-powerful smart contract, the blockchain and the related technologies are indeed disruptive for the banking and financial services industries. They cannot be taken for granted. They consequently face multiple challenges including legal, regulatory and competition barriers to achieve market penetration and as financial intermediation media. Therefore, more research initiatives, sandbox trials and multidisciplinary research collaborations in the field of Shariah, Islamic commercial jurisprudence, computer science and internet are needed. Such a collaboration would ensure the technologies can attain their potential, realize their commercial viability and eventually to be adopted in the mainstream. 
Muneeza \& Mustapha $\mid$ The Potential of Fintech in Enhancing The Use of Salam Contract in Islamic Banking

\section{References}

Abdul Rahman, Y., (2010). The art of islamic banking and finance, USAHoboken: John Wiley Finance. \& Sons, Inc.

Abozaid, A. (2010, ). Personal finance by tawarruq and organized salam. Retrieved January 5, 2020, from http://abdulazeemabozaid.com/en/category/media-interviewsarticles/media-articles-in-arabic/.

Abu Dhabi Commercial Bank, (n.d.). Salam personal finance process flow. Retrieved August 19, 2019 from https://www.adcb.com/islamicbanking/finances/salampersonal/Sala m_Personal_Finance_Process_Flow.asp

Aburaida, K. M. M. (2014). Rural finance as a mechanism for poverty alleviation in Sudan, with an emphasis on "Salam" Mode. European Scientific Journal, 7(26), 157-166.

Ahmed, M. A. (2007). Shariah opinion (fatwa) on Istisna contract and salam, department of research and development, Al-Barka Banking Group. Retrieved January 15, 2020, from Available [online] at http://www.albaraka.com/media/pdf/Research-Studies/RSIS200706201-EN.pdf (Accessed December 8, 2019).

Ajmal, M. M., Rafay, A., \& Sadiq, R. (2017). Pricing of bai salam: an analytical perspective,. International Journal of Business and Society 18(S1), 167-176.

Al-baraka Bank, (n.d.). Salam. Retrieved June 17, 2019 from http://www.albaraka.com.sd/index.php/en/pages/details/51/46.

Al-Barakah Bank, (n.d.). Trading. Retrieved June 17, 2019 from http://www.al-baraka.com/products.php?key=crop\&section=trading.

Al-Zaabi, O. S. (2010). Salam contract in Islamic law: A survey. Review of Islamic Economics, 14(2), 91-122.

Amine, M. B. M (2008). Risk management in Islamic finance: an analysis of derivatives instruments in commodity markets. Leiden: Brill, Netherlands, 337.

Amine, M. B. M. (2001). Istisna' in Islamic banking and finance, law \& practice. Kuala Lumpur, Malaysia: A.S. Noordeen.

Amjad, A. (2015). Impact of Bai Salam on financial inclusion and Agroproduction Business: A case of wheat producing small farmers in Faisalabad (Unpublished Doctoral Dissertation)., Lahore: COMSATS Institute of Information Technology, Pakistan, 342. 
Muneeza \& Mustapha $\mid$ The Potential of Fintech in Enhancing The Use of Salam Contract in Islamic Banking

Awan, S. H., Ahmed, S., Safwan, N., Najam, Z., Hashim, M. Z., \& Safdar, T., (2019). Role of internet of things (IoT) with blockchain technology for the development of smart farming. Journal of Mechanics of Continua and Mathematical Sciences, 14(5), 170-188.

Ayub, M. (2007). Understanding Islamic finance., Hoboken: John Wiley \& Sons, Inc., USA.

Banerjee, A., (2019). Blockchain with IOT: Applications and use cases for a new paradigm of supply chain driving efficiency and cost. Advances in Computers, 115, 259-292.

Bank Negara Malaysia., (2016). Islamic finance development. Retrieved on February 1, 2020, 2018 from https://www.bnm.gov.my/files/publication/fsps/en/2016/cp04.pdf.

Bank Negara Malaysia. (2018). Policy Document BNM/RH/PD029-3 - . Capital Adequacy Framework for Islamic Banks (Risk-Weighted Assets). Retrieved February 11, 2020, from Available [Online] at http://www.bnm.gov.my/index.php?ch=57\&pg=137\&ac=537\&bb=fil e (Accessed 22 December 2019).

Beer, A., \& Faulkner, D. (2014). How to use primary and secondary data. In Stimpson, R. J. (Ed.), Handbook of Research Methods and Applications in Spatially Integrated Social Science (pp. 192-209). Northampton: Edward Elgar Publishing.

Calcaterra, C. and \& Kaal, W. A. (2020). Reputation protocol for the internet of trust. In Compagnucci, M. C., et al. (Eds.),. Legal Tech and the New Sharing Economy: Perspectives in Law, Business and Innovation, Singapore: Springer Nature Pte Ltd., 123-147. DOI: 10.1007/978-98115-1350-3_8.

Chermack, T. J., \& Passmore, D. L. (2005). Using journals and databases in research. Research in organizations: Foundations and methods of inquiry, 401-418.

Christidis, K., \& Devetsikiotis, M. (2016). Blockchains and smart contracts for the internet of things. IEEE Access, 4, 2292-2303.

Cownie, F. and Bradney, A. (2013). Socio-legal studies: a challenge to the doctrinal approach. In Watkins D. and Burton M. (Eds), Research Methods in Law (pp. 42-62). Singapore: Routledge.

Dchieche, A., \& Aboulaich, R. (2016). New approach to model salam contract for profit and loss sharing. International Journal of Applied Engineering Research, 11(2), 909-916.

Drisko, J. W., \& Maschi, T. (2016). Content analysis - pocket guides to social work research methods. New York: Oxford University Press. 
Muneeza \& Mustapha $\mid$ The Potential of Fintech in Enhancing The Use of Salam Contract in Islamic Banking

Ebrahim, M. S., \& Rahman, S. (2005). On the pareto-optimality of futures contracts over Islamic forward contracts: Implications for the Emerging Muslim Economies, Journal of Economic Behaviour \& Organization, 56(2), 273-295. DOI: 10.1016/j.jebo.2003.09.007.

Ehsan, A., \& Shahzad, M. A. (2015). Bay' Salam: A Proposed Model for Shariah Compliant Agriculture Financing. Business \& Economic Review, 7(1), 67-80.

Ge, L., Brewster, C., Spek, J., Smeenk, A., \& Top, J. (2017). Blockchain for Agriculture \& Food - Findings from Pilot Study. Wageningen: Wageningen Economic Research Report: Netherlands, 34.

Giancaspro, M. (2017). Is a 'smart Contract' really a Smart Idea? Insights from a legal perspective. Computer Law and Security Review, 33(6), 825835.

Global Islamic Finance Report (2011). Islamic Retail Banking Products. 50-53. Retrieved February 11, 2020, from Available [Online] at http://www.gifr.net/gifr2011/contents/ch_03.PDF (Accessed 18 December 2019).

Harran, S. Foh Sen, A.Y. \& Haji Masri, S.A. (2010). An Islamic microfinance enterprise: The financial vehicle that will change the face of the Islamic world - the power of salam financing. Bloomington: Xlibris Publishing, USA. International Conference in Islamic Finance 2010, Brunei.

Hassan, R., Muneeza, A., \& Wisham, I. (2011). Reconciling the Dual Banking System: Application Model for Salam Contracts in Malaysia., Malayan Law Journal 5, 59-79.

Hisham, A. F. B., \& Jaffar, M. M. (2017, August). Modeling Commodity Salam Contract between Two Parties for Discrete and Continuous Time Series. In Salleh, Zabidin et al., (Eds.), AIP Conference Proceedings, (Vol. 1870, No. 1, pp. 040-022), . Kuala Terengganu, Malaysia. Melville: AIP Publishing, LLC, USA..

Hutchinson, T. (2015). The doctrinal method: incorporating interdisciplinary methods in reforming the law. Erasmus Law Review, 8, 130-138.

Ibn Abidin, (1996). Hashiyat Rad al Muhtar, Cairo, Egypt: Al- Babi al Halabi, . 209. (cited in Amine, M.B.M., (2008). Risk Management in Islamic Finance: An Analysis of Derivatives Instruments in Commodity Markets, Leiden: Brill, Netherlands, 63).

Izhar, H., \& Hassan, Z. S. A. (2013). Applying Core Principles of Risk Management in Islamic Banks' Operational Risk Analysis. Afro Eurasian Studies, 2(1-2), 15-40. 
Muneeza \& Mustapha $\mid$ The Potential of Fintech in Enhancing The Use of Salam Contract in Islamic Banking

Kaleem, A. \& Wajid, R.A. (2009). Application of Islamic banking instrument (Bai Salam) for Agriculture financing in Pakistan. British Food Journal, 111(3), 275-292.

Kaleem, A., \& Ahmad, S. (2016). Bankers' perception towards bai salam method for agriculture financing in Pakistan. In Harrison, T. \& Ibrahim, E. (Eds.). Islamic Finance: Principles, Performance and Prospects, London: Palgrave Macmillan, 192.

Kamilaris, A., Fonts, A. and \& Prenafeta-Boldu, F.X. (2019). The rise of blockchain technology in agriculture and food supply chains. Trends in Food Science and Technology, 91, 640-652.

Kurniawansyah, D., \& Agustia, D. (2017). A parallel bai' as-salam financing mechanism for banana farmers, micro enterprises and medium enterprises. Advanced Science Letters, 23(9), 8530-8534.

Mansuri, M.T., (2006), Islamic law of contracts and business transactions. New Delhi, India: Adam Publishers \& Distributors.

Mayer, I. (2015). Qualitative research with a focus on qualitative data analysis. International Journal of Sales, Retailing and Marketing, 4(9), 53-67.

Miah, M. D., \& Suzuki, Y. (2018). A critique to a naive critique to 'murabaha' 'tawarruq' syndrome. In Suzuki, Y. \& Miah, M. D., (Eds.), Dilemmas and Challenges in Islamic Finance: Looking at Equity and Microfinance, $1^{\text {st }}$ ed., London, England: Routledge, 234.

Moser, A., \& Korstjens, I. (2018). Practical guidance to qualitative research. Part 3: Sampling, data collection and analysis. European Journal of General Practice, 24(1), 9-18.

Muneeza, A., Yusuf, N. N. A., \& Hassan, R. (2011). The possibility of application of Salam in Malaysian Islamic banking system. Humanomics, 27(2), 138-147. DOI: 10.1108/08288661111135135.

Muneeza, A., Zainudin, N. A., Ali, R., Ibrahim, S. N., \& Mustapha, Z. (2019). Application of ta'widh and gharamah in Islamic banking in Malaysia. The Journal of Muamalat and Islamic Finance Research, 16(1), 1-16.

Obaidullah, M. (2015). Enhancing food security with Islamic microfinance: insights from some recent experiments. Agricultural Finance Review, 75(2), 142-168.

Obaidullah, M., \& Mohamed-Saleem, A. (2008). Innovations in islamic microfinance: lessons from muslim aid's Sri Lankan experiment. Islamic Microfinance Working Paper Series No. 01-09, 16. Retrieved February 15, 2010 from Available [Online] at https://ssrn.com/abstract=1506075. (Accessed December 8, 2019). 
Muneeza \& Mustapha $\mid$ The Potential of Fintech in Enhancing The Use of Salam Contract in Islamic Banking

Onwuegbuzie, A. J., Leech, N. L., \& Collins, K. M. (2010). Innovative data collection strategies in qualitative research. Qualitative Report, 15(3), 696-726.

Peters, G. W., \& Panayi, E. (2016). Understanding modern banking ledgers through blockchain technologies: Future of transaction processing and smart contracts on the internet of money. In Tasca, P. et al., (Eds.), Banking Beyond Banks and Money (pp. 239-278), Cham: Springer., 239-278.

Pilkington, M. (2016). Blockchain technology: Principles and applications. In Olleros, F., and Zhegu, M. (Eds). Research Handbook on Digital Transformations (pp. , 225-253), Northampton: Edward Elgar Publishing..

Razali, S. S. (2012). Revisiting the principles of gharar (uncertainty) in Islamic banking financing instruments with special reference to bay al-inah and bay al-dayn: towards a new modified model. International Journal of Financial Management, 2(1), 33-43.

Rosly, S.A., \& Ismail, H. H. (2010). Salam as a mode of agriculture finance in Malaysia: An analysis of risk-taking behaviour of contracting parties. Available [Online] Retrieved June 17, 2019 from at https://www.scribd.com/document/153519109/Salam-as-a-Modeof-Agri-Finnance-by-Saiful-Rosly-and-Hamdan.

Sahih Bukhari. (1979). Muhmmad Muhsin Khan (trans). Lahore, Pakistan: Qazi Publication.

Saiti, B., Afghan, M., \& Noordin, N.H. (2018). Financing agricultural activities in Afghanistan: a proposed salam-based crowdfunding structure. ISRA International Journal of Islamic Finance, 10(1), 52-61.

Saqib, L. (2011). Financing agriculture through islamic commercial transaction (theory and practice). $1^{\text {st }}$ edition, Latvia, Riga, Latvia: Lambert Academic Publishing, 192.

Saqib, L., Roberts, K. W., Zafar, M. A. \& Khan, K. (2014). Salam (advance payment sale): A realistic approach to the concept in Islamic finance and its application to the agricultural sector in Pakistan. Hamdard Islamicus, 37(3), 43-83.

Sciforce, (2019). Smart farming: The future of agriculture. Retrieved on $28^{\text {th }}$ October 28, 2019 from https://www.iotforall.com/smart-farmingfuture-of-agriculture/.

Shaun Crawford, S., Meadows, I., \& Piesse, D. (2019). Blockchain technology as a platform for digitization: implications for the insurance industry. Ernest \& Young. Retrieved October 28, 2019 from Available [Online] at https://www.ey.com/Publication/vwLUAssets/EY-blockchaintechnology-as-a-platform-for-digitization/\$FILE/EY-blockchain- 
Muneeza \& Mustapha $\mid$ The Potential of Fintech in Enhancing The Use of Salam Contract in Islamic Banking

technology-as-a-platform-for-digitization.pdf (Accessed 20 December 2019).

Sonnenfeld, G. (2019). Zage blockchain report - real world applications of blockchain technology: $q$ \& a o: on blockchain technology use now and into the future. in Zage Blockchain Report - Real World Applications of Blockchain Technology, Retrieved December 12, 2019 from p. 42. Available [Online] at https://zage.io/report/. (Accessed 12 December 2019).

State Bank of Pakistan. (2017). Manual on salam based financing for farm/crop production purposes. Retrieved on 12 February 12, 20198 from http://www.sbp.org.pk/acd/2011/C3-Annx.pdf.

Suayb, G. A. (2010). islamic structured trade finance: a case of cotton production in West Africa. International Journal of Islamic and Middle Eastern Finance and Management, 3(1), 20-35.

Sundararajan, V. (2013). Risk characteristics of Islamic products: implications for risk measurement and supervision. In Archer, S. and Karim, R.A.A. (Eds.) Islamic finance: The regulatory challenge (pp. 49-75), Singapore: John Wiley \& Sons, Pte., Singapore, 49-75.

Usmani U. A. (2019), Sharia rulings of bill discounting and its alternatives. In: Hassan F., Osman I., Kassim E., Haris B., Hassan, R. (Eds.) Contemporary Management and Science Issues in the Halal Industry (pp. 495-508.). Singapore: Springer.r, Singapore,

Utama, S., Suwarsi, A. A., \& Listiono. (2019). The role of Islamic banking in agriculture financing (case study of Indonesian agriculture sector). Humanities and Social Sciences Reviews, 7(2), 261-269.

Webley, L. (2010). Qualitative approaches to empirical legal research. In (Eds.), Cane, P. \& Kritzer, H. M., The Oxford handbook of empirical legal research (pp. 926-950), New York: Oxford University Press.

Yu, L., Zhang, G., Jia, J., Gao, W., \& Tao, S., et al. (2017). Modern agricultural product supply chain based on blockchain technology. Transactions of the Chinese Society for Agricultural Machinery, 48, 387-393.

Yusoff, M., \& Kamdari, A. (2016). The Contract of bay-al-salam and bay-alistisna in Islamic commercial law: A comparative analysis. Prosiding Persidangan Kebangsaan Ekonomi Malaysia Ke-11, Vol. 1, (pp. 590 594), July 27-28, Putrajaya: Malaysia..

Zheng, Z., Xie, S., Dai, H., Chen, X., \& Wang, H. (2017). An overview of blockchain technology: Architecture, consensus, and future trends. In IEEE International Congress on Big Data 2017 (BigData Congress) Proceedings, (pp. 557-564), December 11-14, Boston: USA. 
Muneeza \& Mustapha | The Potential of Fintech in Enhancing The Use of Salam Contract in Islamic Banking

Zuhaily, W. (2007). Financial transactions in Islamic jurisprudence, Vol. 1 (English Translation) 2nd Edition, Damascus: Dar Al Fikr. 